\title{
Durability of Fe-N/C Catalysts with Different Nanostructures for Electrochemical Oxygen Reduction in Alkaline Solution
}

\author{
DING Sheng ${ }^{1}$, NING Kai ${ }^{1}$, YUAN Binxia ${ }^{1}$, PAN Weiguo ${ }^{1,2}$, YIN Shibin $^{3}$, LIU Jianfeng ${ }^{1,2,3}$
}

(1. College of Energy and Mechanical Engineering, Shanghai University of Electric Power, Shanghai 200090, China; 2. Key Laboratory of Environmental Protection Technology for Clean Power Generation in Machinery Industry, Shanghai 200090, China; 3. Key Laboratory of New Processing Technology for Non-ferrous Metals and Materials (Ministry of Education), Guangxi Key Laboratory of Processing for Non-ferrous Metals and Featured Materials, Nanning 530004, China)

\begin{abstract}
The mechanism of Fe-N/C catalysts in oxygen reduction reactions is critical to the development of efficient, sustainable non-noble metal catalysts in polymer electrolyte membrane fuel cells, but it is still in controversy. In order to understand the relationship between composition and the nanostructure of material and the electrochemical activity, this study developed a type of $\mathrm{Fe}-\mathrm{N} / \mathrm{C}$ catalyst with high electrochemical activity, which contained $\mathrm{Fe}-\mathrm{N}_{x}$ active sites and $\mathrm{Fe} / \mathrm{Fe}_{3} \mathrm{C}$ nanocrystals encapsulated with nitrogen-doped carbon nanotubes. Despite being free of precious metals, the as-prepared catalyst displays high oxygen reduction reactions (ORR) activity in alkaline medium with the half-wave potential of $0.86 \mathrm{~V}(v s$ RHE), the mass activity of $18.84 \mathrm{~A} / \mathrm{g}$ at $0.77 \mathrm{~V}(v s \mathrm{RHE})$, and the maximum current density of $-4.3 \mathrm{~mA} \cdot \mathrm{cm}^{-2}$. Meanwhile, the electron transfer number is 3.7 at $0.2 \mathrm{~V}(v s \mathrm{RHE})$, revealing that the 4-electron ORR reaction exists in the catalyst. The excellent electrochemical activity is attributed to the graphene-encapsulated metallic $\mathrm{Fe} / \mathrm{Fe}_{3} \mathrm{C}$ nanocrystals which improves the conductivity after the growth of $\mathrm{N}$-doped carbon nanotubes, and the relatively high proportion of $\mathrm{Fe}-\mathrm{N}_{x}$ active sites distributed on the surface of $\mathrm{Fe} / \mathrm{Fe}_{3} \mathrm{C}$ nanoparticles. This study provides a certain reference and basis for the further study of non-noble metal catalyst and their wide application in commercial production.
\end{abstract}

Key words: electrochemistry; catalyst; nanomaterial; oxygen reduction reaction

Fuel cells are known as the replacement of fossil fuels for their great power density, high efficiency, environmental protection, and reliability. The electrochemical oxygen reduction plays an important role in polymer electrolyte membrane fuel cells (PEMFCs). The sluggish ORR in PEMFC cathode requires highly activated catalysts, among which the platinum-based materials are mainly used. However, platinum-based catalysts are generally expensive, rare and nondurable. In addition, carbon corrosion, platinum dissolution, maturation and shedding of nanoparticles lead to the deterioration of Pt-based catalyst over time. All of these limited the widespread commercial application of PEMFCs.

One of the main methods to solve these problems is to replace platinum-based catalysts with non-noble metal catalysts (NNMC, such as Fe-N/C catalysts). In Fe-N/C catalysts, various active sites have been studied, includ- ing quaternary nitrogen or pyridine nitrogen ${ }^{[1]}$, graphite

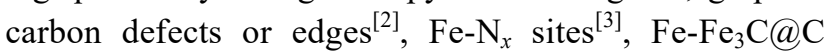

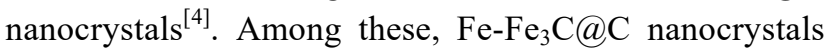
and $\mathrm{Fe}-\mathrm{N}_{x}$ sites are considered as the predominant. Some researchers have revealed the ORR mechanisms of Fe- $\mathrm{N}_{x}$ sites and $\mathrm{Fe}-\mathrm{Fe}_{3} \mathrm{C} @ \mathrm{C}$ nanocrystals ${ }^{[3-4]} . \mathrm{Fe}-\mathrm{N}_{x}$ dominantly catalyzes the reduction of oxygen via 4-electron ORR,

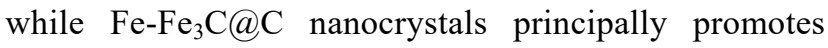
2-electron reduction of oxygen and subsequently catalyzes peroxide. The 4-electron ORR is more efficient and selective than the 2-electron ORR, so the electrochemical activity of $\mathrm{Fe}-\mathrm{N}_{x}$ moieties is better than that of $\mathrm{Fe}-\mathrm{Fe}_{3} \mathrm{C} @ \mathrm{C}$ nanocrystals encapsulated in N-doped carbon ${ }^{[5-7]}$. Many studies on preparation revealed the mechanism of these active sites in recent years, especially those on the $\mathrm{Fe}-\mathrm{N}_{x}$ and $\mathrm{Fe}-\mathrm{Fe}_{3} \mathrm{C} @ \mathrm{C}$ nanocrystals ${ }^{[6-8]}$. However, there are still a lot of controversies about the relationship between catalyst structure and catalytic performance.

Received date: 2019-10-28; Revised date: $2020-02-28$

Foundation item: Young Eastern Scholar (QD 2016052); Open Foundation of Guangxi Key Laboratory of Processing for Non-ferrous Metal and Featured Materials (2020GXYSOF17)

Biography: DING Sheng (1994-), male, Master candidate. E-mail: dingsheng1994@foxmail.com

丁 昇(1994-), 男, 硕士研究生. E-mail: dingsheng1994@foxmail.com

Corresponding author: LIU Jianfeng, associate professor. E-mail: janice.liujianfeng@gmail.com 刘建峰，副教授. E-mail: janice.liujianfeng@gmail.com 
This study aims to reveal the effect of nanostructures of Fe-N/C catalysts on ORR activity. Hence, dicyandiamide and melamine were utilized to regulate the micromorphology of N-doped carbon nanotubes (N-CNTs) and core-shell structure. This study opens up new avenues to enhance the electrochemical activity of ORR catalysts and provides a feasible method for the rational design of catalysts in the future.

\section{Experimental}

\subsection{Synthesis of $\mathrm{Fe}-\mathrm{N} / \mathrm{C}$ catalysts and Pt-decorated carbon black (Pt/CB)}

$0.2 \mathrm{~g} \mathrm{~KB}$ (Ketjenblack, EC-600JD, Lion Co., Ltd) was dispersed in $50 \mathrm{~mL}$ absolute alcohol and ultrasonic for $30 \mathrm{~min}$. $2.02 \mathrm{~g}$ iron (III) nitrate nonahydrate $\left(\mathrm{Fe}\left(\mathrm{NO}_{3}\right)_{3} \cdot 9 \mathrm{H}_{2} \mathrm{O}\right.$, Wako) was added and stirred at $25{ }^{\circ} \mathrm{C}$ for $24 \mathrm{~h}$. The product was filtered and dried at $60{ }^{\circ} \mathrm{C}$. The receiving powder was ground with $2.0 \mathrm{~g}$ dicyandiamide (Aladdin Industrial Co., Ltd) until turning grizzle, and then pyrolyzed at $900{ }^{\circ} \mathrm{C}$ for $1 \mathrm{~h}\left(\mathrm{~N}_{2}, 50 \mathrm{~mL} \cdot \mathrm{min}^{-1}\right.$, $5{ }^{\circ} \mathrm{C} \cdot \mathrm{min}^{-1}$ ). The product was labeled as FeNC-DCDA. $2.0 \mathrm{~g}$ melamine (Aladdin Industrial Co., Ltd) was used to replace dicyandiamide with the same preparation process. The resulting powder was labeled as FeNC-MM. Pt/C was prepared according to the literature [9-10].

\subsection{Materials characterization}

The samples were characterized by field emission scanning electron microscope (FE-SEM, HITACHI S-4800), transmission electron microscope (TEM, Tecnai F20 S-TWIN, FEI), X-ray powder diffraction (XRD, BRUKER D8 ADVANCE Diffractometer, Bruker, with $\mathrm{Cu} \mathrm{K} \alpha$ radiation), and X-ray photoelectron spectroscope (XPS, ESCALAB 250Xi, Thermo scientific).

The experimental methods for electrochemical characterization including electrode preparation, half-cell measurements and load-cycling durability measurements were listed in the supporting materials.

\section{Results and discussion}

\subsection{Physical and chemical properties}

The morphologies of the samples were detected by SEM and TEM. FeNC-DCDA shows an interconnected and parallel CNT framework, which envelope the $\mathrm{Fe}$ nanoparticles (Fig. 1(a)). The CNTs structures serve as fibrous shells to prevent the aggregation of Fe particles. They also enhance the conductivity and electrochemical activity. The $\mathrm{Fe}$ nanoparticles distributed in the nodes and tips of CNTs are separated by wall, and thus keep the moderate size. FeNC-MM (Fig. 1(b)) exhibits nanoparticlelike micromorphology, similar to KB matrix.
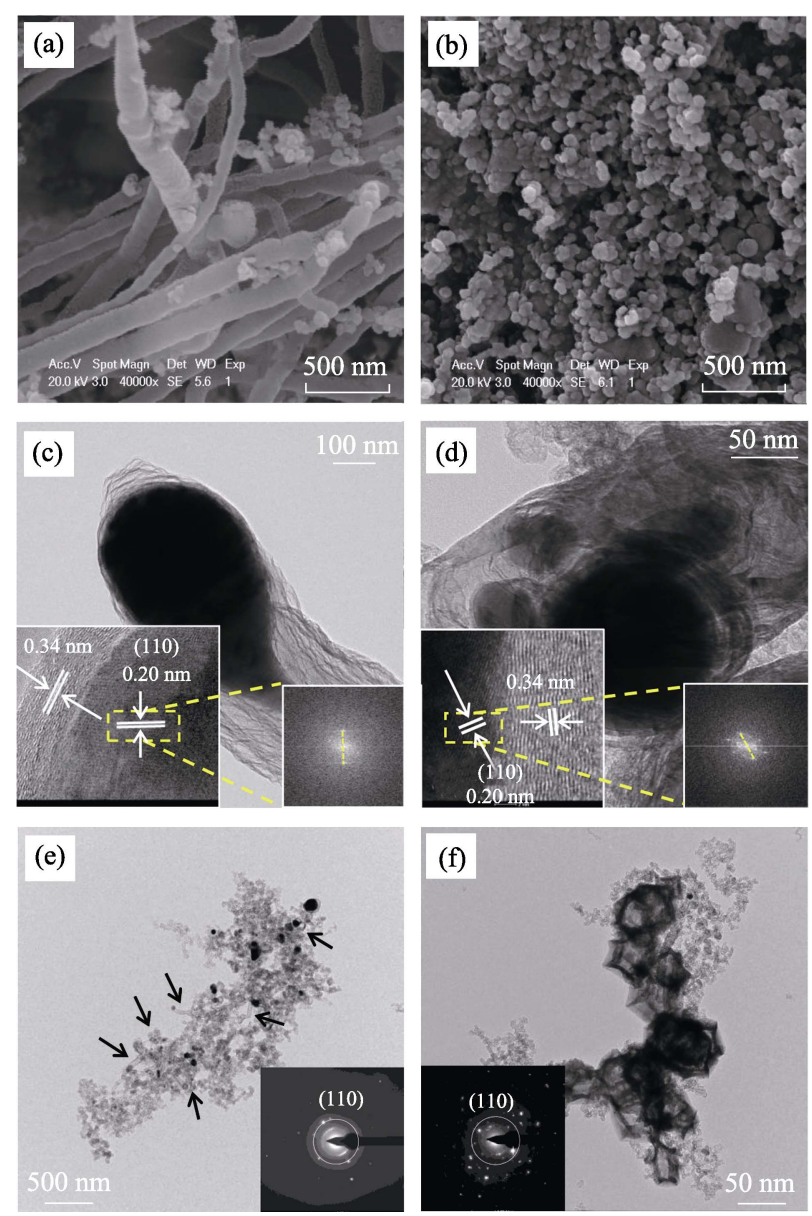

Fig. 1 SEM images of (a) FeNC-DCDA and (b) FeNC-MM; HRTEM images of (c) FeNC-DCDA and (d) FeNC-MM with insets showing corresponding FFT patterns; TEM images of (e) FeNC-DCDA and (f) FeNC-MM with insets showing corresponding SAED images

TEM images of FeNC-DCDA (Fig. 1(c, e)) show that some nanoparticles are embedded or attached to CNTs. These structures enhance the mass transfer rates of reactants and products. The split points in the fast Fourier transform (FFT) pattern from HRTEM images (insets in Fig. 1(c-d)) demonstrate that the lattice spacing of dark nanoparticle is $0.20 \mathrm{~nm}$, corresponding to the (110) crystal plane of the metallic Fe phase. The lattice spacing of the outer graphene layers is $0.34 \mathrm{~nm}$, corresponding to the (002) crystal plane of graphite carbon. The Fe nanocrystal of FeNC-MM (Fig. 1(d)) is coated by thick graphene layers through the closer observation of a single nanoparticle. Further observation of the single nanotube (Fig. S1(a)) shows that the Fe nanoparticles are encapsulated by the graphite layers and located at the tips and nodes of N-doped CNTs, indicating the tip-growth mechanism. Fig. S1(a-b) show that the large Fe nanoparticles split into smaller segments during the in-situ growth of CNTs, which controls the size of grapheneencapsulated metallic $\mathrm{Fe}-\mathrm{Fe}_{3} \mathrm{C}$ nanocrystals so as to avert the formation of larger nanoparticles. The fact that the 
CNTs in FeNC-DCDA (the arrows in Fig. 1(e)) are rarely observed in FeNC-MM (Fig. 1(f)) reveals that the melamine cannot support the formation of CNTs. Meanwhile, dark areas in FeNC-MM are much larger than those of Fe nanoparticles encased in CNTs for FeNC-DCDA (Fig. $1(\mathrm{e}-\mathrm{f})$ ). The selected area electron diffraction (SAED) patterns (insets in Fig. 1(e-f)) also demonstrate the existence of Fe (110) crystal plane, which is consistent with FFT patterns in Fig. 1(c-d).

Fig. 2(a) shows XRD patterns for FeNC-DCDA and FeNC-MM. A prominent C (002) peak of FeNC-MM locates at $2 \theta=26^{\circ}$, indicating certain degree of graphitization. A strong diffraction peak at $2 \theta=44.7^{\circ}$ attributed to the Fe (110) crystal plane (JCPDS 87-0721) matches the crystal diffraction of metallic $\alpha-\mathrm{Fe}$, as well as 2 noteworthy peaks at $2 \theta=65^{\circ}$ and $82^{\circ}$. These peaks reveal that the carbon shells coated on the Fe nanoparticles successfully protect the metallic $\mathrm{Fe}$ from oxidization. Several small peaks in FeNC-MM $\left(2 \theta=42.9^{\circ}, 43.7^{\circ}, 44.6^{\circ}\right.$, $45^{\circ}$ ) suggest the existence of $\mathrm{Fe}_{3} \mathrm{C}$ (JCPDS 35-0772). Several smaller peaks from $2 \theta=30^{\circ}$ to $40^{\circ}$ are likely assigned to the iron oxides nanoparticles which have not been reduced during the annealing process.

The XRD pattern of FeNC-DCDA is similar to that of FeNC-MM. However, the low intense peaks from $2 \theta=42^{\circ}$ to $45^{\circ}$ are indistinguishable except the one located at $2 \theta=43.7^{\circ}$ due to the small size of $\mathrm{Fe}$ particles and N-CNTs structure (Fig. 1(e-f)).

Fig. 2(b-d) show XPS spectra of the catalysts, indicating that nitrogen atoms are successfully doped into the
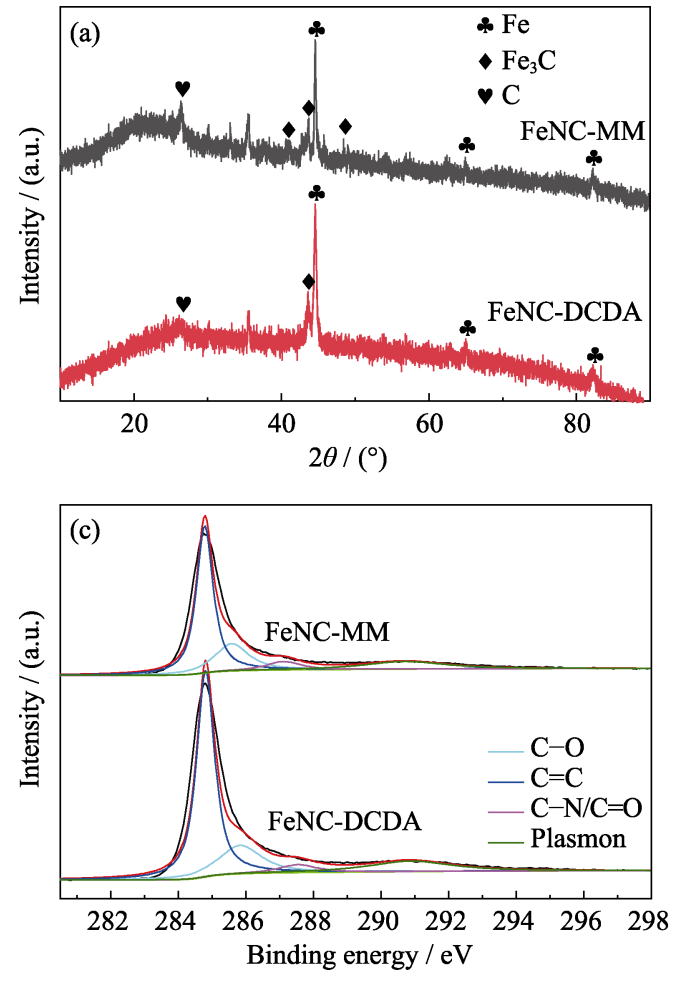

carbon framework of FeNC-DCDA and FeNC-MM materials. FeNC-DCDA and FeNC-MM display N1s peaks at around $398 \mathrm{eV}$ with nitrogen contents of $0.25 \mathrm{at} \%$ and 1.85 at $\%$ (Table S1).

XPS C1s curves of FeNC-DCDA and FeNC-MM (Fig. 2(c)) both center at $284.7 \mathrm{eV}$ and have a tail at higher binding energy. The C1s spectra (Fig. 2(c)) are deconvoluted into binding energies that are attributed to $\mathrm{C}=\mathrm{C}(284.75 \mathrm{eV})$, $\mathrm{C}-\mathrm{O}(285.4 \mathrm{eV}), \mathrm{C}-\mathrm{N} / \mathrm{C}=\mathrm{O}(287.28 \mathrm{eV})$ and plasmon $(290.99 \mathrm{eV})$, respectively ${ }^{[11]}$. This indicates that the graphitized carbon material and $\mathrm{N}$ atoms are successfully doped into the carbon matrix.

Four peaks in N 1s XPS spectra of FeNC-DCDA and FeNC-MM (Fig. 2(d)) correspond to $\mathrm{N}^{-} \mathrm{C}(398.71 \mathrm{eV})$, iron nitrides $(399.82 \mathrm{eV})$, graphitic nitrogen $(401.38 \mathrm{eV})$ and oxygenated nitrogen $(403.51 \mathrm{eV})^{[5,12]}$, and the nitrogen compound contents are elaborated in Table S2.

The signals at around 398.68 and $401.26 \mathrm{eV}$ are assigned to $\mathrm{N}-\mathrm{C}$ and graphitic nitrogen, respectively. The different nitrogen sources for both catalysts result in the different graphitic nitrogen contents between FeNCDCDA and FeNC-MM. The graphitic nitrogen content for FeNC-DCDA is significantly higher than that for FeNC-MM. Intensification of the peak at $\sim 400 \mathrm{eV}$ is attributed to the increase of Fe- $\mathrm{N}_{x}$ content (Table S2).

\subsection{Electrochemical characterization}

The electrochemical activity was evaluated by cyclic voltammetry (CV) and linear sweep voltammetry (LSV) in $\mathrm{O}_{2}$-saturated and $\mathrm{N}_{2}$-saturated $0.1 \mathrm{~mol} \cdot \mathrm{L}^{-1} \mathrm{KOH}$. From LSV curves (Fig. 3(a)), the onset potential of $\mathrm{Pt} / \mathrm{C}$ is $1.065 \mathrm{~V}$ ( $v s$ RHE) and the mass diffusion-limited current density
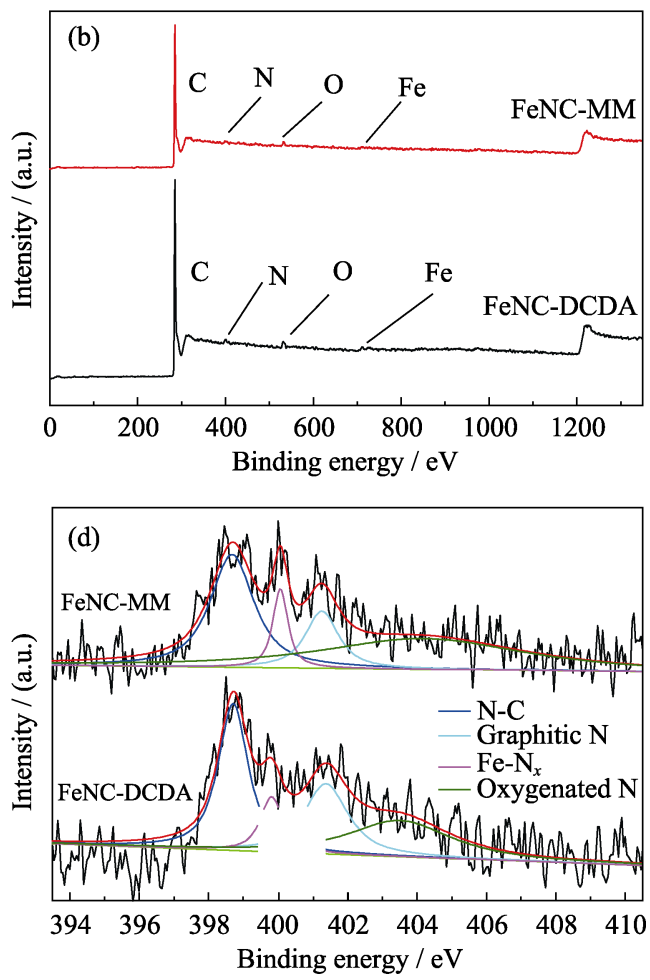

Fig. 2 XRD patterns (a), XPS wide scan (b), XPS C1s spectra (c), XPS N1s spectra (d) for FeNC-DCDA and FeNC-MM 

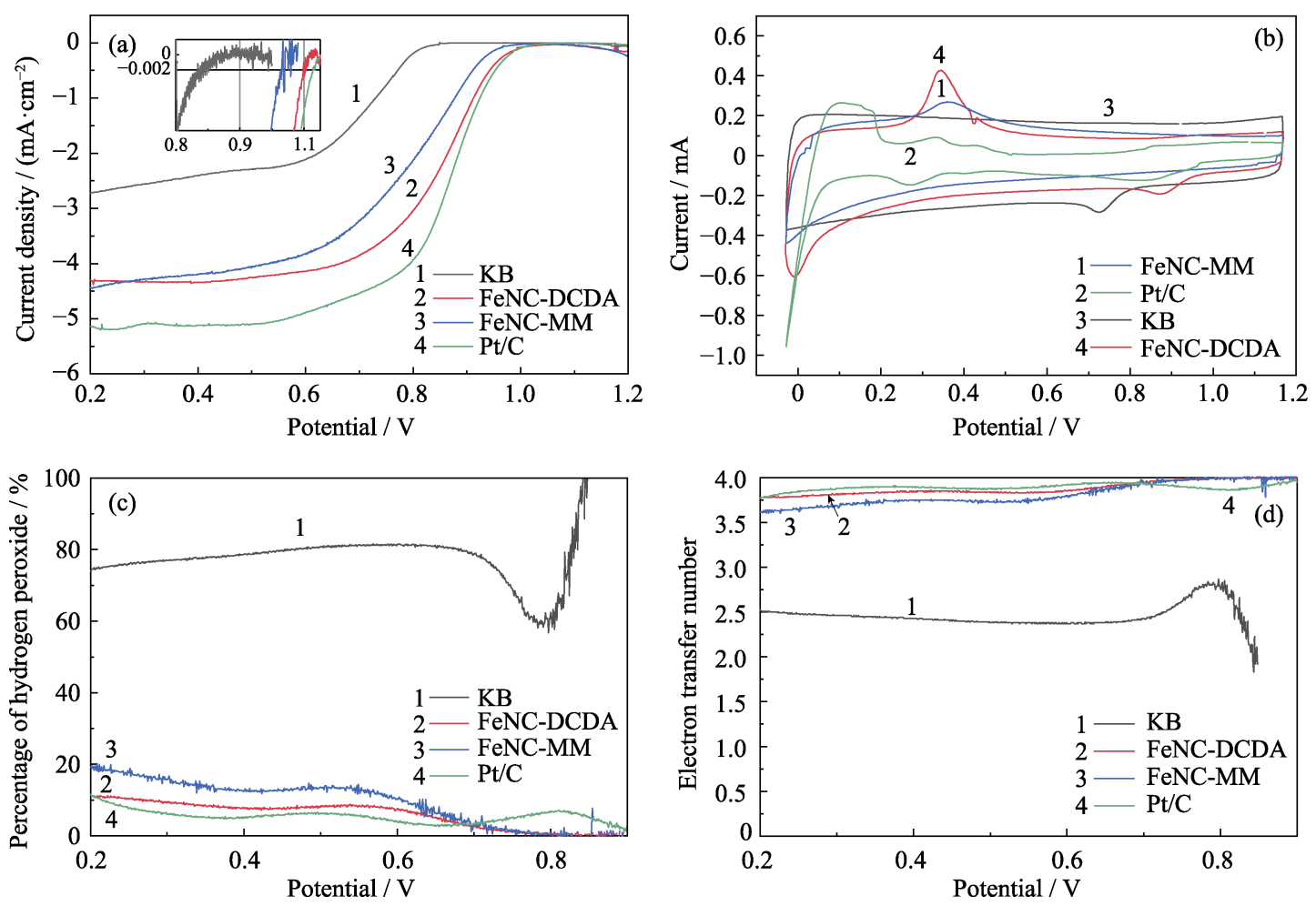

Fig. 3 LSV curves (a), CV curves (b), $\mathrm{H}_{2} \mathrm{O}_{2}$ yield (c) and electron transfer number (d) for $\mathrm{Pt} / \mathrm{C}$, FeNC-DCDA, FeNC-MM and $\mathrm{KB}$ in $\mathrm{O}_{2}$-saturated $0.1 \mathrm{~mol} \cdot \mathrm{L}^{-1} \mathrm{KOH}$ at $1600 \mathrm{r} \cdot \mathrm{min}^{-1}$

is $-5.14 \mathrm{~mA} \cdot \mathrm{cm}^{-2}$ at $1600 \mathrm{r} \cdot \mathrm{min}^{-1}$. The onset potential for $\mathrm{KB}$ is $0.89 \mathrm{~V}(v s \mathrm{RHE})$, and the mass diffusion-limited current density is $-2.73 \mathrm{~mA} \cdot \mathrm{cm}^{-2}$, which are much lower than those of Pt/C. For FeNC-DCDA, the onset potential is $1.055 \mathrm{~V}(v s$ RHE) which is only $10 \mathrm{mV}$ lower than $\mathrm{Pt} / \mathrm{C}$, and the mass diffusion-limited current density is $-4.3 \mathrm{~mA} \cdot \mathrm{cm}^{-2}$. FeNC-MM also displays high initial activity with the onset potential of $1.02 \mathrm{~V}(v s$ RHE) and the mass diffusion-limited current density of $-4.44 \mathrm{~mA} \cdot \mathrm{cm}^{-2}$ which are close to those of $\mathrm{Pt} / \mathrm{C}$, but lower than FeNC-DCDA. The half-wave potentials for $\mathrm{KB}$, FeNC-MM, FeNC-DCDA, and Pt/C are 0.697, 0.792, 0.857 , and $0.865 \mathrm{~V}(v s \mathrm{RHE})$ respectively which are consistent with their onset potential trends. The mass activity of the $\mathrm{Pt} / \mathrm{C}$ is defined as the kinetically controlled current per gram of $\mathrm{Pt}\left(\right.$ i.e. $\left.\mathrm{A} \cdot \mathrm{g}_{\mathrm{Pt}}^{-1}\right)$. For non-noble catalysts, the mass activity is defined as the kinetically controlled current per gram of catalyst. Thus, the mass activities are calculated as $2.12 \mathrm{~A} \cdot \mathrm{g}_{\mathrm{KB}}^{-1}$, $18.84 \mathrm{~A} \cdot \mathrm{g}_{\mathrm{FeNC}-\mathrm{DCDA}}^{-1}$, and $17.32 \mathrm{~A} \cdot \mathrm{g}_{\mathrm{FeNC}-\mathrm{MM}}^{-1}$ and $1017.65 \mathrm{~A} \cdot \mathrm{g}_{\mathrm{Pt}}^{-1}$ at $0.77 \mathrm{~V}(v s \mathrm{RHE})$. These results show that the FeNCDCDA possesses higher onset potential, half-wave potential and mass activity than FeNC-MM, indicating the better electrochemical activity.

The CV curve of Pt/C (Fig. 3(b)) displays an oxidation/ reduction peak of $\mathrm{PtO}_{x}$ with potential above $0.6 \mathrm{~V}(v s \mathrm{RHE})$ and a double-layer capacitance region ranging from 0.5 to $0.6 \mathrm{~V}(v s \mathrm{RHE})$. These data are close to the results reported in the literature [13], suggesting that the as-prepared $\mathrm{Pt} / \mathrm{C}$ catalyst is suitable for reference. The $\mathrm{CV}$ curves of both NNMCs are quasi-rectangular and display no significant redox peaks under $\mathrm{O}_{2}$ conditions, which are the typical characteristics of high specific surface area for carbon materials ${ }^{[14]}$.

All of the resulting metal-containing materials are catalyzed by quasi-four-electron-transfer pathway (Fig. 3(c-d)), while the FeNC-DCDA catalyst owns a higher proportion of 4-electron ORR than FeNC-MM. This indicates that the ratio of 4-electron ORR catalytic sites is much lower in the absence of N-CNTs. The higher initial performance of FeNC-DCDA catalyst may be attributed to its more uniform distribution of the internal $\mathrm{Fe}-\mathrm{Fe}_{3} \mathrm{C}$ nanocrystals which boosts the catalytic activity of $\mathrm{Fe}-\mathrm{N}_{x}$ active sites on the outer surface of the carbon shell ${ }^{[5]}$.

\subsection{Load-cycling durability}

It is critical to maintain activity throughout the service life of the fuel cell. Hence, the durability tests of NNMCs are conducted and compared with $\mathrm{Pt} / \mathrm{C}$ catalyst in this study.

Fig. 4(a-b) are CV and LSV curves of the durability tests for the $\mathrm{Pt} / \mathrm{C}$ catalyst. During the experiment, the oxidation/ reduction peak and hydrogen adsorption/desorption of platinum are significantly reduced, and the half-wave potential decreases by $30 \mathrm{mV}$. This can be contributed to the decline of electrochemical surface area for the aggregation of platinum nanoparticles and the carbon support dissolution or detachment ${ }^{[14]}$. 

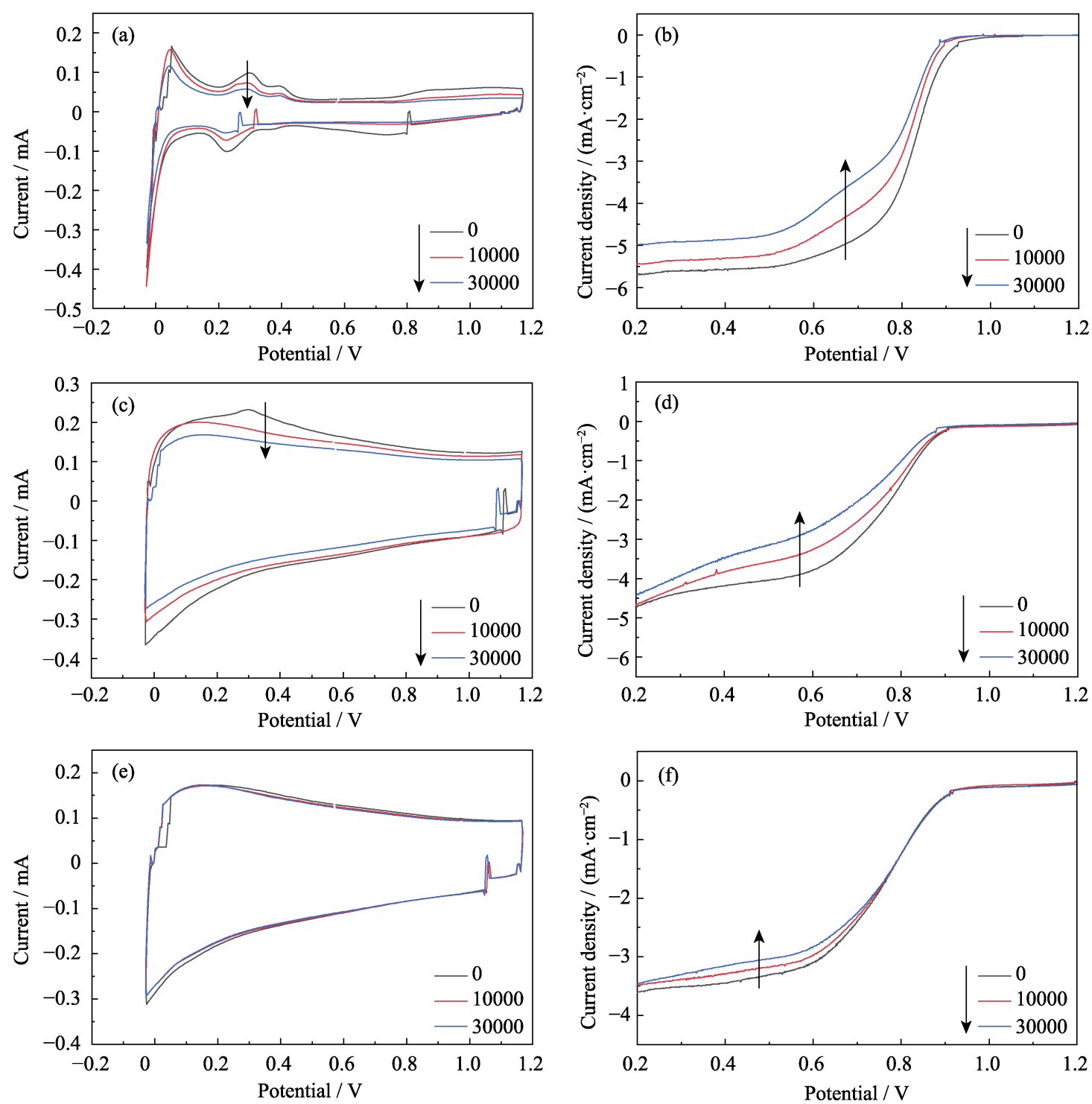

Fig. $4 \mathrm{CV}$ curves in $\mathrm{N}_{2}$-saturated $0.1 \mathrm{~mol} \cdot \mathrm{L}^{-1} \mathrm{KOH}$ and $\mathrm{LSV}$ curves in $\mathrm{O}_{2}$-saturated

$0.1 \mathrm{~mol} \cdot \mathrm{L}^{-1} \mathrm{KOH}$ of the catalysts for 30000 load potential cycles (a-b) Pt/C; (c-d) FeNC-MM; (e-f) FeNC-DCDA

The area of the CV curves for FeNC-MM (Fig. 4(c)) shows a significant drop during the durability test, revealing the change of double-layer capacitance which is associated with the durability of the carbon support. Furthermore, the half-wave potential decreases significantly by $72 \mathrm{mV}$ (Fig. 4(d)), indicating relatively poor cycling performance compared to $\mathrm{Pt} / \mathrm{C}$ catalyst.

After 30000 cycles, the change in CV and LSV curves for FeNC-DCDA (Fig. 4(e-f)) is negligible, indicating its stable ORR activity. The half-wave potential hardly changed throughout the durability test compared with $\mathrm{Pt} / \mathrm{C}$ catalyst. This indicates that the active sites in FeNC-DCDA are more stable than those in $\mathrm{Pt} / \mathrm{C}$ catalyst or somehow prevents electrochemical degradation.

The maximum current density after 30000 cycles of Pt/C, FeNC-MM, and FeNC-DCDA (Fig. S3) dropped to $87.5 \%, 94.1 \%$, and $95.8 \%$ of their initial value. $\mathrm{Pt} / \mathrm{C}$ has the highest initial activity but is unstable during 30000 cycles. FeNC-MM also presents high initial activity, but degrades at a relatively fast rate after 10000 cycles. Its activity is also unstable in the remaining potential cycles. The initial activity of FeNC-DCDA is slightly lower than $\mathrm{Pt} / \mathrm{C}$, but the degradation is negligible, indicating that the FeNC-DCDA is an applicable catalyst for ORR catalysis in alkaline medium.

\section{Conclusions}

In summary, two $\mathrm{Fe} / \mathrm{N}-\mathrm{C}$ catalysts with different nitrogen sources were synthesized and compared to reveal the influence of nitrogen sources on ORR activity. It was found that nitrogen sources affect the nanostructures, micromorphology and electrochemical performance for $\mathrm{Fe} / \mathrm{N}-\mathrm{C}$ catalysts. The analytical results from SEM, TEM, XRD, and XPS confirm the FeNC-DCDA with moderate

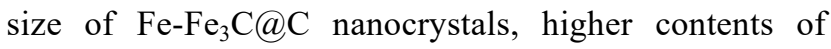


graphitic nitrogen and $\mathrm{Fe}-\mathrm{N}_{x}$ species possesses higher half-wave potential $(0.857 \mathrm{~V}(v s \mathrm{RHE})$, only $8 \mathrm{mV}$ lower than that of $\mathrm{Pt} / \mathrm{C}$ ) and better durability (the maximum current density retention is $95.8 \%$ after 30000 cycles). These characteristics make FeNC-DCDA a catalyst more suitable for ORR in alkaline solution than $\mathrm{Pt} / \mathrm{C}$ catalyst.

\section{Supporting materials}

Supporting materials related to this article can be found at https://doi.org/10.15541/jim20190547.

\section{References:}

[1] YASUDA S, YU L, KIM J, et al. Selective nitrogen doping in graphene for oxygen reduction reactions. Chemical Communications, 2013, 49(83): 9627-9629.

[2] SHEN A, ZOU Y, WANG Q, et al. Oxygen reduction reaction in a droplet on graphite: direct evidence that the edge is more active than the basal plane. Angewandte Chemie International Edition, 2014, 53(40): 10804-10808.

[3] MALKO D, KUCERNAK A, LOPES T. In situ electrochemical quantification of active sites in $\mathrm{Fe}-\mathrm{N} / \mathrm{C}$ non-precious metal catalysts. Nature Communications, 2016, 7: 13285.

[4] VARNELL J A, TSE E C M, SCHULZ C E, et al. Identification of carbon-encapsulated iron nanoparticles as active species in non-precious metal oxygen reduction catalysts. Nature Communications, 2016, 7: 12582.

[5] JIANG W J, GU L, LI L, et al. Understanding the high activity of $\mathrm{Fe}-\mathrm{N}-\mathrm{C}$ electrocatalysts in oxygen reduction: $\mathrm{Fe} / \mathrm{Fe}_{3} \mathrm{C}$ nanoparticles boost the activity of $\mathrm{Fe}-\mathrm{N}_{x}$. Journal of the American Chemical Society, 2016, 138(10): 3570-3578.
[6] CHOI C H, CHOI W S, KASIAN O, et al. Unraveling the nature of sites active toward hydrogen peroxide reduction in Fe-N-C catalysts. Angewandte Chemie International Edition, 2017, 56(30): 8809-8812.

[7] KIM J H, SA Y J, JEONG H Y, et al. Roles of $\mathrm{Fe}-\mathrm{N}_{x}$ and $\mathrm{Fe}^{-} \mathrm{Fe}_{3} \mathrm{C} @ \mathrm{C}$ species in $\mathrm{Fe}-\mathrm{N} / \mathrm{C}$ electrocatalysts for oxygen reduction reaction. ACS Applied Materials \& Interfaces, 2017, 9(11): 9567-9575.

[8] WANG J, WEI Z D. Recent progress in non-precious metal catalysts for oxygen reduction reaction. Acta Physico-Chimica Sinica, 2017, 33(5): 886-902.

[9] ZHAO X J, HAYASHI A, NODA Z, et al. Evaluation of change in nanostructure through the heat treatment of carbon materials and their durability for the start/stop operation of polymer electrolyte fuel cells. Electrochimica Acta, 2013, 97: 33-41.

[10] KANDA K, NODA Z, NAGAMATSU Y, et al. Negligible start-stop-cycle degradation in a PEFC utilizing platinum-decorated tin oxide electrocatalyst layers with carbon fiber filler. ECS Electrochemistry Letters, 2014, 3(4): F15-F18.

[11] LIU J F, CUNNING B V, DAIO T, et al. Nitrogen-doped carbon foam as a highly durable metal-free electrocatalyst for the oxygen reduction reaction in alkaline solution. Electrochimica Acta, 2016, 220: 554-561.

[12] ZAGAL JOSÉ H, BEDIOUI FETHI, DODELET JEAN-POL. N4-Macrocyclic Metal Complexes. New York: Springer, 2006: 83-147.

[13] SA Y J, SEO D J, WOO J, et al. A general approach to preferential formation of active $\mathrm{Fe}-\mathrm{N}_{x}$ sites in $\mathrm{Fe}-\mathrm{N} / \mathrm{C}$ electrocatalysts for efficient oxygen reduction reaction. Journal of the American Chemical Society, 2016, 138(45): 15046-15056.

[14] MUFUNDIRWA A, HARRINGTON G F, SMID B, et al. Durability of template-free Fe-N-C foams for electrochemical oxygen reduction in alkaline solution. Journal of Power Sources, 2018, 375: 244-254.

\title{
碱性溶液中不同微观结构的 Fe-N/C 催化剂 氧还原性能的稳定性对比研究
}

\author{
丁 昇 ${ }^{1}$, 宁 锴 ${ }^{1}$, 袁斌霞 ${ }^{1}$, 潘卫国 ${ }^{1,2}$, 尹诗斌 ${ }^{3}$, 刘建峰 ${ }^{1,2,3}$
}

(1. 上海电力大学 能源与机械工程学院, 上海 200090; 2. 机械工业清洁发电环保技术重点实验室, 上海 200090; 3. 广西有色金属及特色材料加工重点实验室，有色金属及材料加工新技术教育部重点实验室，南宁 530004)

摘 要: $\mathrm{Fe}-\mathrm{N} / \mathrm{C}$ 催化剂在氧还原反应中的作用机理对于开发高效、可持续使用的非贵金属催化剂在聚合物电解质膜 燃料电池中的应用至关重要, 但目前仍存在很多的难以攻克的问题。为了揭示纳米结构与电化学活性的关系, 本研 究开发了一种具有高电化学活性的 Fe-N/C 氧还原催化剂, 该催化剂含有 $\mathrm{Fe}-\mathrm{N}_{x}$ 位点和被氮掺杂的碳纳米管包裹的 $\mathrm{Fe} / \mathrm{Fe}_{3} \mathrm{C}$ 纳米晶体两种具有氧还原反应电化学活性的纳米结构。尽管不含贵金属铂, 本研究合成的 $\mathrm{Fe}-\mathrm{N} / \mathrm{C}$ 催化剂 在碱性条件下仍显示出较高的 ORR 活性, 半波电势为 $0.86 \mathrm{~V}(v s \mathrm{RHE})$, 质量活性为 $18.84 \mathrm{~A} / \mathrm{g}(0.77 \mathrm{~V}(v s \mathrm{RHE})$, 极限 电流密度为 $-4.3 \mathrm{~mA} \cdot \mathrm{cm}^{-2}$ 。同时, 电子转移数为 3.7 (0.2 V $(v s$ RHE), 说明 Fe-N/C 催化剂中 4 电子 ORR 反应的比例 较高。石墨烯包覆的金属 $\mathrm{Fe} / \mathrm{Fe}_{3} \mathrm{C}$ 纳米晶生长 $\mathrm{N}-\mathrm{CNTs}$ 后, 材料的导电性有所提高, 并且 $\mathrm{Fe}-\mathrm{N}_{x}$ 活性位点在 $\mathrm{Fe} / \mathrm{Fe} \mathrm{C}_{3} \mathrm{C}$ 纳米颗粒表面分布均匀, 改善了材料的电化学活性。本研究为非贵金属氧还原电催化剂的继续深入研究以及广泛应 用于商业化生产提供了一定的借鉴和依据。

关 键 词: 电化学; 催化剂; 纳米材料; 氧还原反应

中图分类号: O643 文献标识码: A 
Supporting materials:

\title{
Durability of Fe-N/C Catalysts with Different Nanostructures for Electrochemical Oxygen Reduction in Alkaline Solution
}

\author{
DING Sheng ${ }^{1}$, NING Kai ${ }^{1}$, YUAN Binxia ${ }^{1}$, PAN Weiguo ${ }^{1,2}$, YIN Shibin ${ }^{3}$, LIU Jianfeng ${ }^{1,2,3}$
}

(1. College of Energy and Mechanical Engineering, Shanghai University of Electric Power, Shanghai 200090, China; 2. Key Laboratory of Environmental Protection Technology for Clean Power Generation in Machinery Industry, Shanghai 200090, China; 3. Key Laboratory of New Processing Technology for Non-ferrous Metals and Materials (Ministry of Education), Guangxi Key Laboratory of Processing for Non-ferrous Metals and Featured Materials, Nanning 530004, China)

\section{Electrode preparation}

The working electrode was prepared based on the standard protocol of Fuel Cell Commercialization of Japan $(\mathrm{FCCJ})^{[1]} .6 \mathrm{mg} \mathrm{Fe}-\mathrm{N} / \mathrm{C}$ catalyst was dispersed in the mixed liquor of deionized water, absolute ethyl alcohol and $5 \mathrm{wt} \%$ Nafion solution $(3 / 3 / 1, V / V / V)$ by sonicating in the ice bath for $30 \mathrm{~min}^{[2]}$. For Pt/C catalyst, $3 \mathrm{mg}$ catalyst was put into the mixed liquor of 19/6/0.1 $(V / V / V)$, and sonicated for $30 \mathrm{~min}^{[3]} .10 \mu \mathrm{L}$ ink of $\mathrm{Fe}-\mathrm{N} / \mathrm{C}$ or Pt/C was coated carefully on the disk of a carbon-disk Pt-ring electrode. Subsequently, the electrode was dried at $60{ }^{\circ} \mathrm{C}$ for $10 \mathrm{~min}$. The calculated catalyst loading on the surface of glassy carbon-disk $\left(5 \mathrm{~mm}\right.$ in diameter, $0.196 \mathrm{~cm}^{2}$ in geometric area) was 436.54 and $16.84 \mu \mathrm{g} \cdot \mathrm{cm}^{-2}$ for $\mathrm{Fe}-\mathrm{N} / \mathrm{C}$ and $\mathrm{Pt} / \mathrm{C}$, respectively.

\section{Half-cell measurements}

Half-cell measurements were carried out on rotating ring disk electrode (RRDE) by an electrochemical device (Hokuto Denko Corp., Ltd, HR-301). A platinum-wire (carbon rod in durability tests) was used as the counter electrode, and an $\mathrm{Ag} / \mathrm{AgCl}$ electrode was used as the reference electrode. All tests were carried out in $\mathrm{N}_{2}$-saturated or $\mathrm{O}_{2}$-saturated $0.1 \mathrm{~mol} \cdot \mathrm{L}^{-1} \mathrm{KOH}$ solution at $25{ }^{\circ} \mathrm{C}$. The received voltages were recalculated relative to a reversible hydrogen electrode (RHE).

The CV curves were obtained within 0-1.2 V(vs RHE) at a scan rate of $50 \mathrm{mV} \cdot \mathrm{s}^{-1}$ in $\mathrm{N}_{2}$-saturated $0.1 \mathrm{~mol} \cdot \mathrm{L}^{-1}$ $\mathrm{KOH}$ solution. The number of electron transfer $(n)$ and the $\mathrm{H}_{2} \mathrm{O}_{2}$ yield during the process of oxygen reduction reaction (ORR) were detected by rotating ring disk electrode (RRDE). The LSV curves were obtained within $1.2-0.2 \mathrm{~V}\left(v s\right.$ RHE) at a scan rate of $10 \mathrm{mV} \cdot \mathrm{s}^{-1}$ in $\mathrm{O}_{2}$-saturated solution with different rotate speeds $(400,900$, 1600, and $2500 \mathrm{r} \cdot \mathrm{min}^{-1}$ ). The LSV curves in Fig. 3(a) were obtained by eliminating the blank current curves recorded in the $\mathrm{N}_{2}$-saturated solution in order to eliminate the effects of residual oxygen in electrolyte solution.
The $\mathrm{H}_{2} \mathrm{O}_{2}$ yield and number of electron transfer $(n)$ were calculated by the equations below:

$$
\begin{gathered}
\% \mathrm{HO}_{2}^{-}=200 \times \frac{I_{\mathrm{r}} / N}{I_{\mathrm{d}} \times I_{\mathrm{r}} / N} \\
n=4 \times \frac{I_{\mathrm{d}}}{I_{\mathrm{d}}+I_{\mathrm{r}} / N}
\end{gathered}
$$

Where $I_{\mathrm{d}}$ is disk current, $I_{\mathrm{r}}$ is ring current and $N$, 0.4735 , is the current collection efficiency of the Pt ring carbon disk electrode.

\section{Load-cycling Durability Measurements}

U.S. Department of Energy (U.S. DOE) and FCCJ have clearly defined polymer electrode membrane fuel cell (PEMFC) cycle durability measurement protocols. The PEMFC durability protocols contains start-stop tests to detect carbon corrosion and a duty cycle durability test to evaluate Pt stability. However, the potential of carbon corrosion in alkaline media is different from that in acidic media, which causs that the PEMFC durability protocols do not fit anion exchange membrane fuel cell $(\mathrm{AEMFC})^{[4]}$. This study employed an amended FCCJ scheme for durability tests in alkaline solution. The durability test used a rectangular-wave potential cycle ranging from 0.6 to $1 \mathrm{~V}$ (vs RHE) which was equal to the $\mathrm{PtO}_{x}$ formation peak of $\mathrm{Pt} / \mathrm{C}$ in an alkaline solution ${ }^{[5]}$. Each cycle lasted $6 \mathrm{~s}$, and 30000 cycles was achieved.

\section{Control experiments}

To better support the above conclusions, two control experiments were performed. (1) The catalyst FeNC-DCDA was immersed in $0.5 \mathrm{~mol} \cdot \mathrm{L}^{-1} \mathrm{H}_{2} \mathrm{SO}_{4}$ for $12 \mathrm{~h}$ at $60{ }^{\circ} \mathrm{C}$ to remove $\mathrm{Fe}$ particles. The $\mathrm{Fe}-\mathrm{Fe}_{3} \mathrm{C}$ nanocrystals in the FeNC-DCDA catalyst were reduced, and the ORR activity of acid-leached FeNC-DCDA catalyst was significantly decreased. The half-wave potential at $0.797 \mathrm{~V}(v s \mathrm{RHE})$ was $60 \mathrm{mV}$ lower than the initial electrochemical activity (Fig. $\mathrm{S} 2(\mathrm{a}))$. The microstructure of $\mathrm{Fe}-\mathrm{Fe}_{3} \mathrm{C}$ nanocrystals lead 
(a)

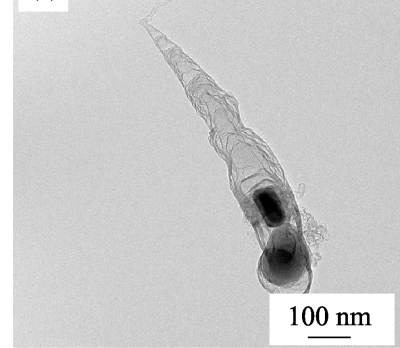

(b)

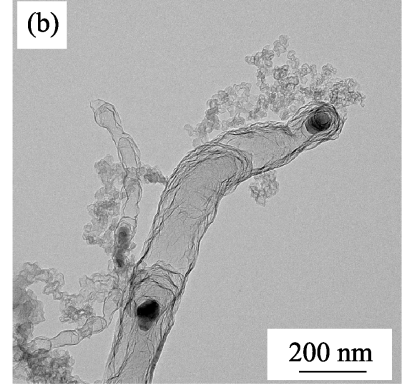

Fig. S1 HRTEM images of FeNC-DCDA
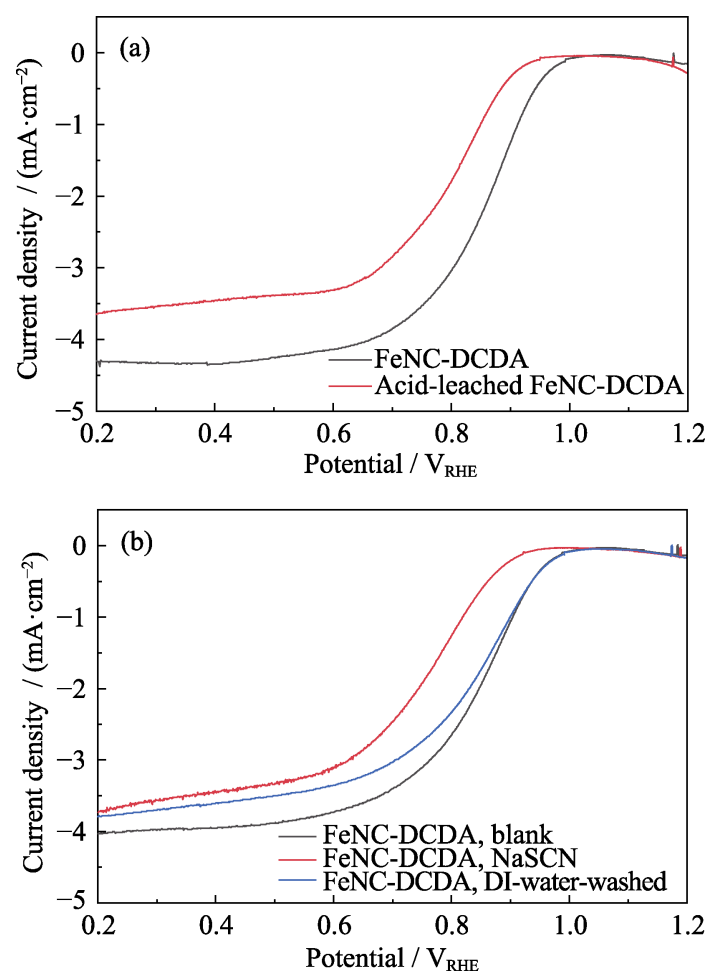

Fig. S2 LSV curves of as-prepared and acid-leached FeNC-DCDA measured in $\mathrm{O}_{2}$-saturated $0.1 \mathrm{~mol} \cdot \mathrm{L}^{-1} \mathrm{KOH}$ (a) and LSV curves of $\mathrm{SCN}^{-}$poisoned FeNC-DCDA measured in $\mathrm{O}_{2}$-saturated $0.1 \mathrm{~mol} \cdot \mathrm{L}^{-1} \mathrm{KOH}\left(1600 \mathrm{r} \cdot \mathrm{min}^{-1}, 10 \mathrm{mV} \cdot \mathrm{s}^{-1}\right)(b)$

to high ORR activity of the catalyst. (2) It is well known that $\mathrm{SCN}^{-}$ion can poison $\mathrm{Fe}-\mathrm{N}_{x}$ active sites in $\mathrm{ORR}^{[6]}$.
FeNC-DCDA catalyst was pretreated by $0.1 \mathrm{~mol} \cdot \mathrm{L}^{-1} \mathrm{KOH}$ solution which contained $0.01 \mathrm{~mol} \cdot \mathrm{L}^{-1} \mathrm{NaSCN}$, then rinsed thoroughly with deionized water for $30 \mathrm{~min}$ and measured in $\mathrm{O}_{2}$-saturated $0.1 \mathrm{~mol} \cdot \mathrm{L}^{-1} \mathrm{KOH}$ solution. The half-wave potential of FeNC-DCDA was significantly reduced by $91 \mathrm{mV}$ after pretreatment with $0.01 \mathrm{~mol} \cdot \mathrm{L}^{-1}$ NaSCN (Fig. S2(b)). The noteworthy inhibitory effect of catalytic activity may be due to the locked Fe- $\mathrm{N}_{x}$ active sites by $\mathrm{SCN}^{-}$ion in ORR. However, the LSV curves gradually returned to the original state after FeNC-DCDA catalyst was washed with deionized water. It is due to the recovery of the locked $\mathrm{Fe}-\mathrm{N}_{x}$ sites in $\mathrm{KOH}$ solution and $\mathrm{SCN}^{-}$dissociation on central iron sites. All of the above results confirm that $\mathrm{Fe}-\mathrm{Fe}_{3} \mathrm{C}$ nanocrystals and $\mathrm{Fe}-\mathrm{N}_{x}$ coordination sites are the source of FeNC-DCDA ORR activity.

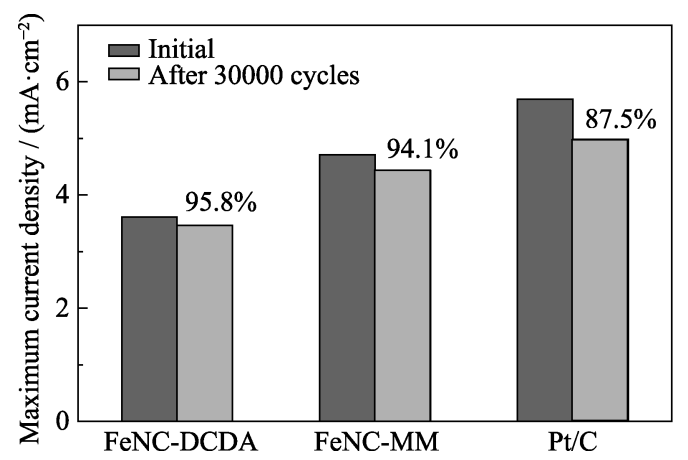

Fig. S3 Comparison of maximum current densities of catalysts before and after the durability tests

Table S1 Elemental compositions of Fe-N/C catalysts synthesized with different nitrogen sources obtained from XPS analysis

\begin{tabular}{ccc}
\hline Composition & FeNC-DCDA/at $\%$ & FeNC-MM/at $\%$ \\
\hline Carbon & 97.05 & 96.14 \\
Nitrogen & 0.25 & 1.85 \\
Oxygen & 2.21 & 1.54 \\
Iron & 0.49 & 0.48 \\
\hline
\end{tabular}

Table S2 Nitrogen contents and deconvoluted N 1s peak positions in Fe-N/C catalysts from XPS data

\begin{tabular}{|c|c|c|c|c|c|c|c|c|}
\hline \multirow{2}{*}{ Catalyst } & \multicolumn{2}{|c|}{$\mathrm{N}-\mathrm{C}$} & \multicolumn{2}{|c|}{$\mathrm{Fe}-\mathrm{N}_{x}$} & \multicolumn{2}{|c|}{ Graphitic nitrogen } & \multicolumn{2}{|c|}{ Oxygenated nitrogen } \\
\hline & Position/eV & Fraction/\% & Position/eV & Fraction/\% & Position/eV & Fraction/\% & Position/eV & Fraction/\% \\
\hline FeNC-DCDA & 398.71 & 35.66 & 399.82 & 10.02 & 401.38 & 24.79 & 403.51 & 29.52 \\
\hline FeNC-MM & 398.68 & 34.54 & 400.07 & 8.4 & 401.26 & 13.2 & 404.2 & 43.86 \\
\hline
\end{tabular}

\section{References:}

[1] OHMA A, SHINOHARA K, IIYAMA A, et al. Membrane and catalyst performance targets for automotive fuel cells by FCCJ membrane, catalyst, MEA WG. ECS Transactions, 2011, 41(1): 775-784.

[2] LYTH S M, NABAE Y, ISLAM N M, et al. Electrochemical oxy- gen reduction activity of carbon nitride supported on carbon black. Journal of the Electrochemical Society, 2011, 158(2): B194-B201.

[3] LIU J F, TAKESHI D, SASAKI K, et al. Defective graphene foam: a platinum catalyst support for PEMFCs. Journal of the Electrochemical Society, 2014, 161(9): F838-F844.

[4] ZADICK A, DUBAU L, SERGENT N, et al. Huge instability of $\mathrm{Pt} / \mathrm{C}$ catalysts in alkaline medium. ACS Catalysis, 2015, 5(8): 4819-4824. 
[5] SHENG W C, GASTEIGER H A, SHAO-HORN Y. Hydrogen oxidation and evolution reaction kinetics on platinum: acid $v s$ alkaline electrolytes. Journal of the Electrochemical Society, 2010, 157(11): B1529-B1536.
[6] THORUM M S, HANKETT J M, GEWIRTH A A. Poisoning the oxygen reduction reaction on carbon-supported $\mathrm{Fe}$ and $\mathrm{Cu}$ electrocatalysts: evidence for metal-centered activity. The Journal of Physical Chemistry Letters, 2011, 2(4): 295-298. 